\title{
Archaeology and Heritage Resource Management in Siuyu, Singida Region (Tanzania)
}

\author{
Makarius Peter Itambu ${ }^{1}$, Nazarius Michael Hongoa ${ }^{2}$ \\ ${ }^{1}$ Department of Archaeology and Heritage, University of Dar Es Salaam, Dar Es Salaam, Tanzania \\ ${ }^{2}$ Demography Unit, University of Dar Es Salaam, Dar Es Salaam, Tanzania \\ Email:mcpeter7@gmail.com,nazariushongoa5@gmail.com
}

Received 9 May 2016; accepted 10 June 2016; published 13 June 2016

Copyright @ 2016 by authors and Scientific Research Publishing Inc.

This work is licensed under the Creative Commons Attribution International License (CC BY). http://creativecommons.org/licenses/by/4.0/

(c) (i) Open Access

\section{Abstract}

This paper was produced as a part of our ongoing research endeavors in Singida destined to provide a better understanding of early humans' cultures, and to promote the conservation of cultural and natural heritages of the region. The overreaching goals of this research are to holistically reconstruct the archaeology of Singida by studying cultural processes over time and space. Equally important is to promote tourism in the Singida eastern axis and, to salvage the heritage assets of the region from total disappearance as evinced by the activities of modern day civilization, broadly, to shed more light about the past life ways, and the subsistence behaviours of our ancestors. Our recent archaeological reconnaissance conducted in January 2016 in Siuyu ward discovered rock paintings and a rock shelter with archeological potential (Ngaghe rock shelter), containing a large scatter of Later Stone Age (LSA) archaeological artifacts that are crucial to the unravelling of the prehistoric human behaviours in Singida. Preliminary results from our research revealed that Singida region is an ideal place for undertaking research on early human bio-cultural evolution from LSA times to the present. Data from this study will be utilized to re-write the history of Singida region, to make sure that it is sustained for future generations. Despite their rarity, uniqueness, scientific and aesthetic values, these heritage assets are neither protected by village nor regional by-laws. Before deliberate conservation measures are put in place, it is very important to have good records of the areas that are attractive to tourism, and their current state of preservation. These sites were undocumented by the previous researchers, and in certain circumstances are unknown even to the local people of the Siuyu ward. Although the archaeology of Singida east is much "terra incognita", this article is timely, for promoting archaeo-tourism and raising public awareness on the archaeology of Singida. Additionally, this work provides a stimulus to the authorities to take action by introducing effective conservation measures for the sustainability of these priceless non-renewable resources. 


\section{Keywords}

\section{Archaeology, Heritage Conservation, Cultural and Natural Resources, Tourism}

\section{Introduction}

The Singida region has been known archaeologically for the last few decades for its endowments of prehistoric rock painting sites. Together with the Dodoma region, the Kondoa Irangi, and the Usandawe areas form the famous belt in central Tanzania with rich and diversified rock paintings made by hunter-foragers and Bantu speaking communities. Significantly, a substantial number of archaeological localities of Later Stone Age (LSA) and Iron Age (IA) have been recovered in Singida dated at approximately 45,000 BP and the 10,000 - 2000 years old.

In terms of archaeological investigations, unlike the Northern axis, Singida eastern axis has had been neglected by researchers. Since the works of Ludwig and Margrit Kohl-Larsen (rock art researchers) in Singida north, Iambi and Iramba plateaus between 1934-1935 and 1958; Masao 1976, 2005, and Mahudi 2008 [1] [2], very little archaeological work has been reported or carried out in Singida east. These early expeditions were thematically similar in the sense that were framed on zonal preferences, and concentrated broadly on surveys and documentation of archaeological sites that were previously reported by the missionaries and colonial administrators. Despite their regional, zonation prejudices, and biases, these scholars produced detailed sketches of the rock paintings subject matter, and published their findings in their books: "Felsmalereien in Innerafrika" and "Die Bilderstrasse Ostafrika" in 1938 and 1958 [1]-[5].

The only notable extensive archaeological investigations in Singida eastern axis were carried by Fidelis Masao [6], followed by a big hiatus before the works of Audax Mabulla and Makarius Itambu in 2014/2015 [7] who surveyed and described the archaeological sites extensively, and studied the meaning and subject matter of the rock art. They also made assessments on the state of preservation of the rock art and their sites [7] and deliberately advocated for community involvement in conservation of natural and cultural heritage of Singida east by launching heritage management awareness campaigns. They also emphasized the importance of participation by the local people in rock art conservation. Some of the sites mentioned by Masao in 1976 were revisited by Mabulla and Itambu in their 2014-2015 expeditions. Their renewed archaeological voyages discovered more archaeological sites in Misughaa, Siuyu (Itraghatra and Misimbwa), Kinku (Ndaa A Ng’ongo), Issanga, Ughaugha, Mahambe, and Mang’onyi that were not initially reported by the early pioneers.

\section{Background Information}

The Singida region is one of the most compelling areas of geological and archaeological research in Tanzania. This region is marked by the impressive and massive, isolated hills, inselbergs and granite outcrops, the land of small and large plateaus, and escarpments that form a unique and beautiful natural landscape. The region is a landlocked one situated in the middle of the country. It lies in the semi-arid zone of Tanzania's central plateau between longitude $33^{\circ} 24^{\prime} \mathrm{E}$ and $35^{\circ} 1 ' 2 \mathrm{E}$ and latitude $3^{\circ} 42^{\prime} \mathrm{S}$ and $7^{\circ} 06^{\prime} \mathrm{S}$ (Figure 1).

This study focused on the Singida eastern axis in the Ikungi district, specifically in areas surrounding and adjoining Siuyu ward. The Ikungi district is one among the five (5) districts forming the Singida region. This is a newly established district formed in 8th, March 2013 through government gazette no. 87. The Ikungi district is within $4^{\circ}$ to $6^{\circ}$ latitudes south of the equator and between $34^{\circ} 45^{\prime}$ to $35^{\circ} 45^{\prime}$ East of Greenwich meridian [1] [7]. The district borders Uyui district of Tabora region in the south, Singida municipal and Singida rural from the north, Iramba from the northwest, Chemba and Kondoa from the northeast and Manyoni from the south. The south-western zone that borders Uyui and Manyoni districts has fertile soils while the rest has less fertile (sandy soil) which is only suitable for production of semi-arid adapted crops [6]. The Ikungi district is made up of four [7] divisions namely Sepuka, Ikungi, Ihanja, and Mungaa (where this area was conducted i.e. Siuyu ward-see Figure 1).

\subsection{Topography, Climate, Peopling and Their Socio-Economic Activities}

Singida region forms part of the semi-arid central zone of Tanzania which experiences low rainfalls and short 


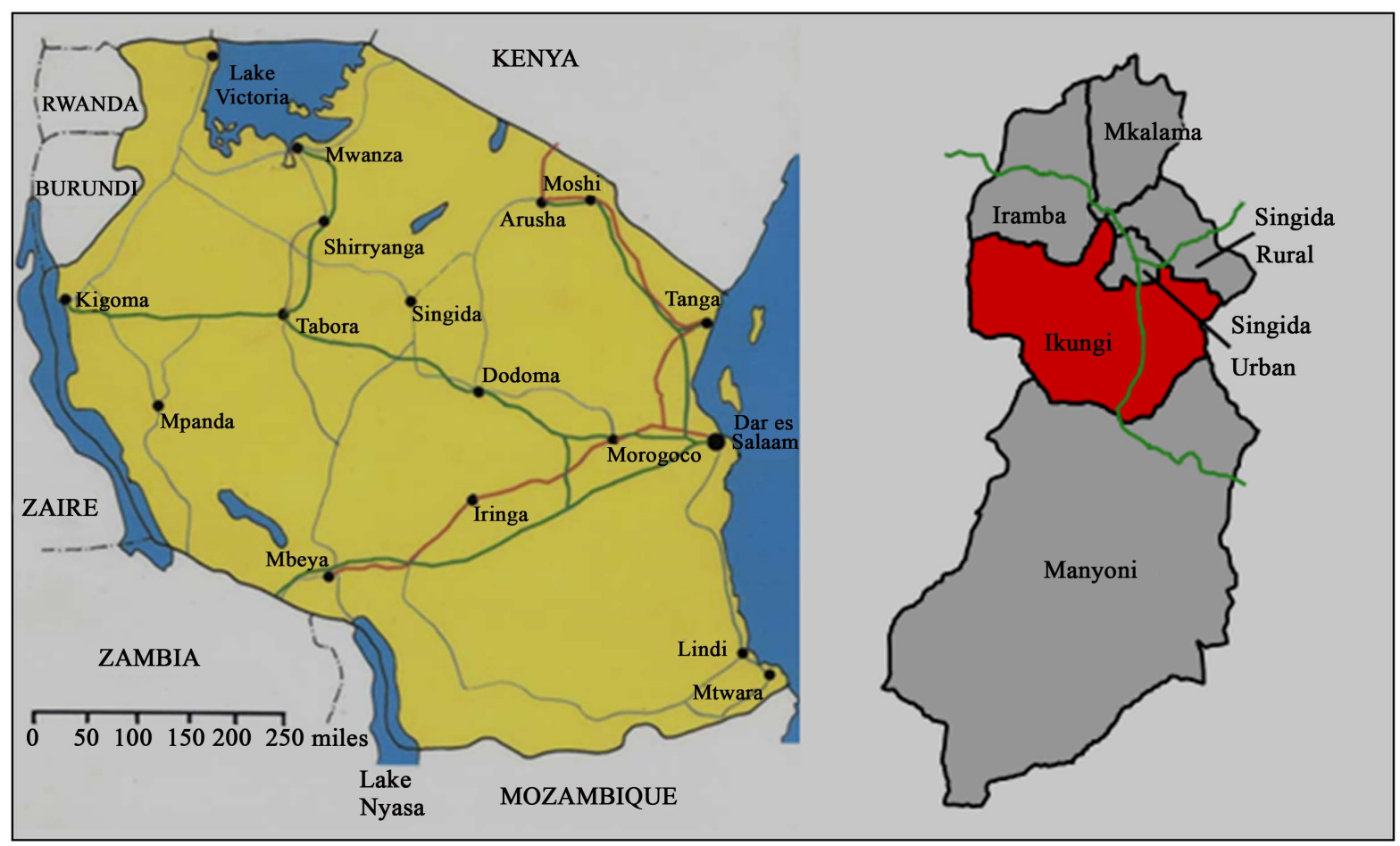

Figure 1. Map of Tanzania showing the location of the study area.

rainy seasons which are often erratic with fairly wide spread droughts in one year out of four [8]. Geologically, the basement rocks which are type of Dodoman system are ubiquitous in the region and they are part of the Dodoman system, formerly referred to as the Lower Basement Complex [8] [9]. These rocks consist of a complex of pellitic schists, granitic gneisses and migmatites, ranging in mineral composition from potassic granite to diorite [7].

The prototype vegetation of Singida region and central Tanzania in general is consisting of savanna woodlands (largely miombo or Brachystegia sp.) with small pockets of montane forests and savannahs [1]-[4]. Contemporary intensification of tree clearing for agricultural activities, timber, and wood for house construction, firewood, and charcoal burning have greatly reduced the amount of natural biomes. In the study area, savanna woodlands composed of Brachystegia sp. still exist in Ngimu-Mugori, Mwisi, Lighwa, Ntewa-Ntutu, ThrauMang'onyi and Musule-Misughaa, though threatened by human activities. Animal husbandry and other anthropogenic activities have reduced the natural habitats and the number of wild animals.

The Ikungi district experiences even temperatures, with minima and maxima of $15^{\circ} \mathrm{C}$ and $30^{\circ} \mathrm{C}$ respectively. Nonetheless, there has been notable rise in ambient temperatures in the last four decades. The annual rainfall ranges from $600 \mathrm{~mm}$ to $700 \mathrm{~mm}$. These climatic conditions favour the production of certain types of semi-arid adapted agricultural crops. The district has three main agro-economic zones, namely; the northern zone, the south west, and the eastern zone that lies within the vicinity of the Rift Valley.

The Wanyaturu (Turu/Rimi/Arimi people), and Wanyiramba, the predominant tribal groups in the area, are small-scale agriculturalists and cattle herders that are generally living in cleared areas close to the margins of the woodland. The Ikungi district is chiefly inhabited by agro-pastoral Wanyaturu that are forming about $95 \%$ of the total population [7]. The remaining $5 \%$ is composed of the hunter-foragers Wasandawe, and the pastoral Wabarbaig and Wadatoga tribes. Although agro-pastoralism has been practiced in this area, presently crops husbandry is the chief economic activity with about $90 \%$ of the residents depending on it as the source of their livelihoods.

Predominantly, the Singida rural and Ikungi areas among Wanyaturu are deeply attached to livestock and simple cropping systems. The shifting cultivation of sorghum, millet, and finger-millet forms an integral part of their daily diet. Other agricultural crops grown in this part include sweet potatoes, sunflower, beans, groundnuts, and maize. On top of that, one can argue that sunflower cultivation within homesteads has attained a status of a 
dominant cash crop. This cash crop, in contrast with the past, is acting as a substitute to food crops, due to the fact that it superbly withstands the arid soils of the region. The limited resource-base and poor aridic soils, and variable rainfalls has resulted in food shortages in the months of December, January, and February. The northern zone bordering Singida district council and Singida municipal, made up of the Ihanja and Sepuka divisions, has very fertile gravel-loamy and clay soils that favours the production of various crops. Agricultural crops produced in this part of the region include sorghum, finger millet, cassava, sunflower, onions, millet, sweet potatoes and lentils (dengu).

The eastern zone is occupied by the East African Rift Valley and is bordered by Kondoa district (Dodoma region) and Singida municipality. This zone occupies Ikungi and Mungaa divisions. The surface of Wahi-Arimi, the sub-tribal area in which this study was conducted (Siuyu Ward) is desiccated and undulated with hills, ridges, and bottom valleys of marshy land that are suitable for growing potatoes [7]. It is estimated that about 15 percent of the workforce in the district engages in other activities such as timber, fishing, small industries (sunflower oil processing) and small scale mining (salt) activities. This part of the Singida eastern axis are primarily settled by Wahi and Anyamunying'anyi-Wanyaturu. Their livestock are grazed on the open lands around the village or in the nearby forests until the grass is gone; otherwise the marshes are expected to support them during the dry seasons of June to November.

In some villages, however; there are forest reserves that provide not only building materials, medicine, and parts for tools, but also fuel. Customarily and frequently, this is gathered by the women, while men are responsible for traditional houses construction, other construction work, and cattle grazing. Unfortunately, the agricultural sector has been negatively affected by a number of factors such as arid climatic conditions (dependence on rain fed agriculture) and poor physical infrastructure, particularly roads. As a result, people's incomes in the district has been affected. The average farm size per peasant household is 5 acres of a subsistence farm. At this moment in time, a by-law has passed stipulating a district "by-law" that requires a farmer to have 2 acres of each food and cash crops respectively to ensure food security. They are encouraged to grow semi-arid climatetolerant, and disease-resistant crops such as cassava and sweet potatoes because of the drought nature and general episodic drying trends of the region (Mwl. Pius Jingu pers. comm., January 2016).

\subsection{Study Area Profile}

Siuyu (S $5^{\circ} 07^{\prime} 59.00^{\prime \prime}$, E $\left.39^{\circ} 46^{\prime} 0.01^{\prime \prime}\right)$ is an administrative ward in the newly Ikungi district formerly known as Singida rural district. According to the 2002 census, the ward had a total population of 8632 [10] but due to the improvement of social services, the population size is estimated to be presently around 12,000.

Around the vicinity of Siuyu ward there is a bunch of inselberg hills, kopjes, and ridges that are separated by mbughaa bottom valleys (black-clay soils), common everywhere in the Singida eastern axis. They are also marked by the ubiquitous granite outcroppings, sometimes of giant proportions, that appear here and there in every village (Ngong'o A Urimi as the most popular one). The internal drainage of the Siuyu created marshy lands and swamps, traditionally called "mbuugha" (black cotton soils/cracking clays). These clay-black cotton soils are composed of calcareous [11]. These black fissured clays vary greatly in size-from small patches which dry out quickly when the rains stop, to giant expanses, especially in the Singida depression, some of which, like lake Mugori and Muyanji dam hold surface water perennially. Since most depressions are shallow and hold only a little surface water, the swamp grasslands "Inyee" can be used for grazing during dry seasons (i.e. Mudenku, Malelemi, Nali-Nghage Donye). These unusual semi-arid conditions, combined with the fact that the swamps are numerous and provide a permanent water-supply, has had been a highly significant factor in the consolidation of sedentary settlements that led to the collapse of nomadic pastoralism.

The livelihoods of the majority of inhabitants of Wahi-Arimi in Siuyu (Figure 1) are mainly dependent on agriculture (crop production) and livestock keeping and, in particular, indigenous poultry. To a lesser extent, horticulture (neighbouring permanent swamps), and small business enterprises that forms the extra-economic activities of most of the Ikungi inhabitants. The district economy is heavily tilted towards agriculture as more than 85 percent of the population are engaged in crop cultivation and livestock keeping. However, the level of agricultural mechanization is very low with large a proportion of the farmers solely depending on the traditional hand hoe for tilling arable lands.

In all aspects of life, patriarchy is highly dominant in Singida east. The men are the decision-makers and women are mainly responsible for children-rearing and other domestic duties. However, women's workloads in 
the study area is not correlative to men's daily duties due to the fact that women are more productive, chief producers, and important contributors to household incomes.

Our research identified that most of the archaeological sites in Singida eastern axis look like Kondoa (Plate 1) localities. They appear high up on silent bush covered hillsides, invariably overlooking some plains, a valley or a river. Seldom do these sites occur on low-lying ground and such is also the case with most of the South African rock art sites. Several reasons have been provided for such locations to have been favored. Hill slope sites commanded wide, lovely views out over far reaching plains and immediate areas around providing the best vantage point, for watching for game or for self-defence against their foes (also see Figure 2 [1]-[4] [6] [7] [12]).

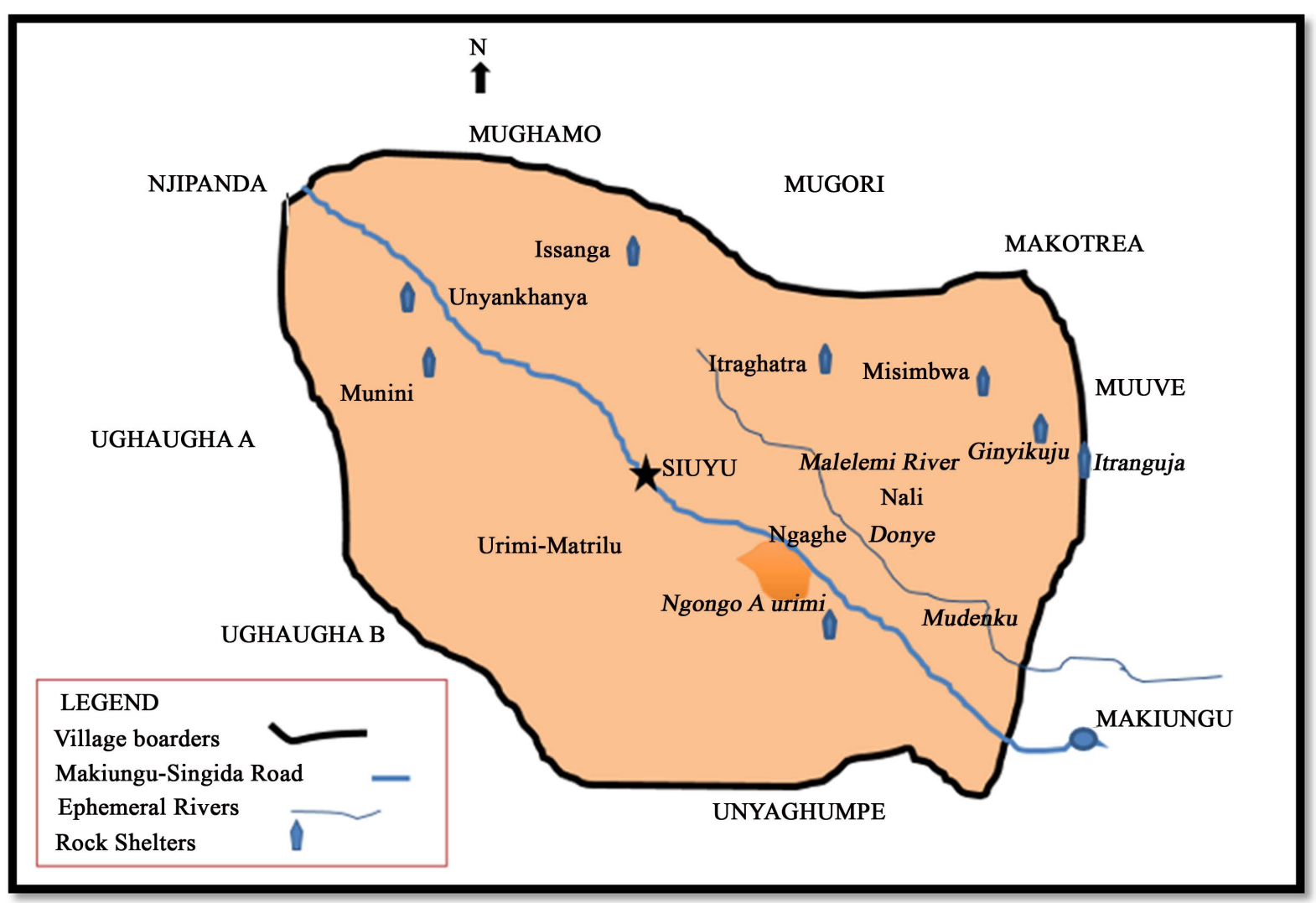

Figure 2. Map of Siuyu village showing location of the Ngaghe rock shelter.

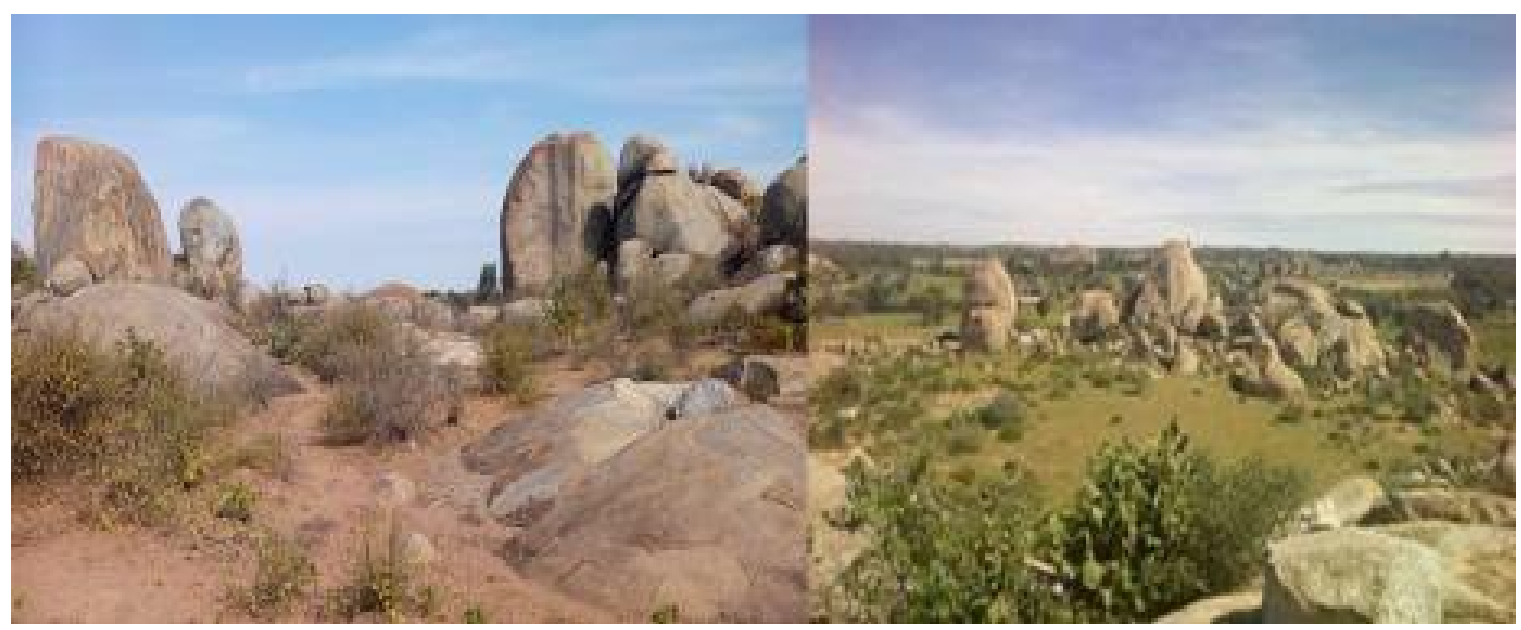

Plate 1. Ngaghe granite outcrops in Siuyu ward (Photo: Courtesy of Fr. A. Bukenya \& Ambrose Leo Dede). 


\section{Materials and Methods}

\subsection{Ethnographic Enquiries and Surveys}

The geographical location of a rock art sites was documented using a hand-held Global Positioning System (GPS) device. We also used a high-resolution Sony digital camera for photographs. In some cases, ethnographic enquiries were employed in order to get supplementary information. Besides, we interviewed local people in order to assess their general understanding of the natural beauty of the rock boulders, and other heritage resources that are potential for touristic activities in Siuyu. We did this because we wanted to know whether there are any traditional approaches/strategies in which they have been practicing or involved in the management and conservation of these resources.

Furthermore, we needed to spot archaeological sites and artifact distribution as indicated by the surface scatter of archaeological materials. This was very crucial in identifying potential sites to be excavated in the near future. Thereafter, followed an intensive survey whereby we looked at the nature of the landscape, the altitude, natural vegetation type, and proximity to the water sources since they might possibly have influenced the painters to choose the site [3] [4] [13] [14].

Simultaneously, the fieldwork team looked at material cultures occurring on the surface. Due to the rough, rocky terrain of Siuyu ward, we decided to conduct a deliberate/purposive sampling technique. We mainly focused on the naturally exposed granite rock boulders, and rock shelters with general assessments on the panoramic view of the landscape. The hilly nature of the sites forced us to conduct unsystematic surveys that involved walkovers across the Precambrian granite outcrops, without being guided by systematic grid boxes or transects of any kind as archaeological surveys normally undertaken (see Plate 2).

\subsection{Survey Results}

\subsubsection{Ngaghe Rock Shelter (UTM 36 M 0713662/9455875)}

This rock shelter has an elevation of $1355 \mathrm{~m}$, located at about $2.5 \mathrm{~km}$ southwest of Siuyu ward (E $7^{\circ} 39^{\prime} 32^{\prime \prime}$; S $\left.34^{\circ} 28^{\prime} 22^{\prime \prime}\right)$. The site is surrounded by Precambrian granite-kopjes and inselbergs, and the general vicinity of the rock shelter and its landscape is largely composed of LSA stone artefacts, slag and potsherds (Plate 3). The

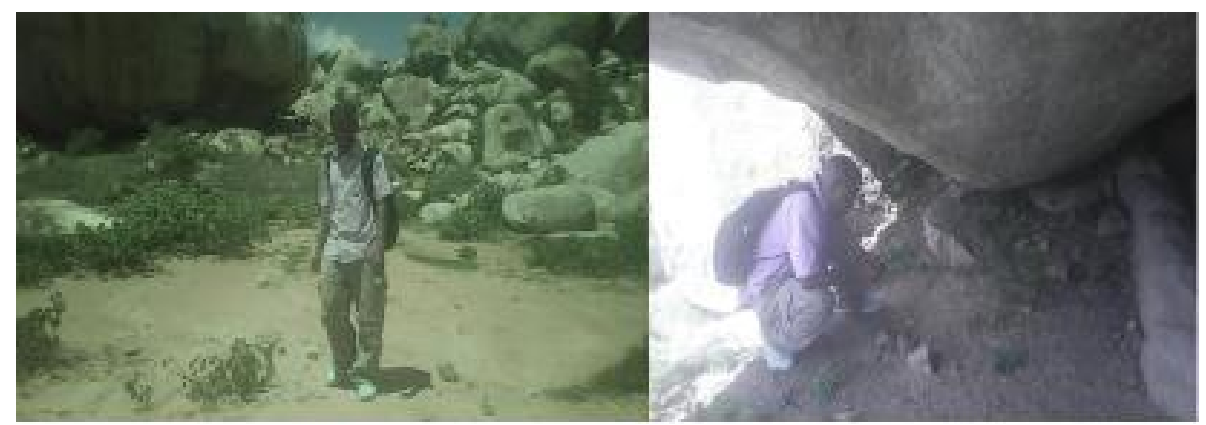

Plate 2. A reconnaissance survey in Ngaghe rock shelter (Photo credits to N. M. Hongoa 2016).
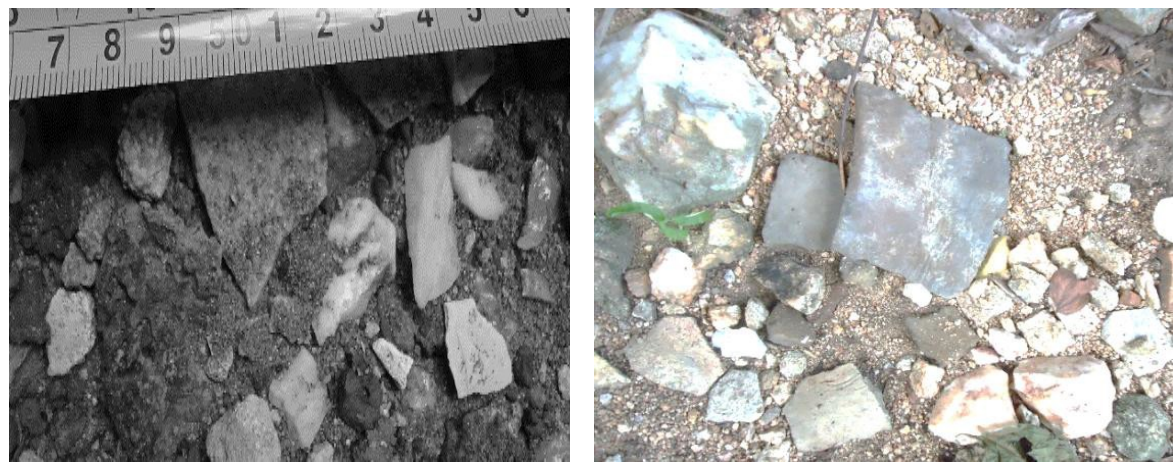

Plate 3. The scatters of LSA Stone tools (Quartz) \& IA potsherds under the Ngaghe rock shelter's floor. 
geomorphology and ecological settings of the archaeological site is correlative and similar to other rock painting sites that had been reported in Kondoa, Lake Eyasi basin, Meatu and Iringa, as both are consisting of a massive inland plateau with isolated mountains and numerous granite exposures of the Precambrian era ([3]-[5] [12][14]).

In most parts of the study area, the rock shelters with archaeological artifacts occur mainly in the highlands, and they are commonly scattered along the Precambrian granite rock outcrops. Dry forests, shrubs, bush savannah and occasionally grassy plains surround these rocky highlands. Our ancestors (prehistoric people) probably selected mountainous landscapes for arty executions as the painted arts can probably survive longer [14], or for security reasons/defence as the geomorphology of the landscape discourages and limits access to potentially dangerous wild animals. In spite of its archaeological potential, the sites' temporal encroachment threatens its survival e.g. the wild sisal fence put in the proximity by the Pallottine Catholic Missionaries to demarcate the boundaries of their marshy farmlands they recently bought from the village government.

\subsubsection{Itramuka Rock Paintings Site}

Itramuka rock painting is found in the Itramuka hills in Misimbwa hamlet of Siuyu Ward. The northeastern side of Misimbwa is dominated by scatters of isolated hills and rocks that continue eastward to join the Mugori rift escarpment. These hills and the associated rift escarpment is what is known as the Itramuka hills and escarpment, and is the location of the hunter-foragers faded rock paintings [7]. The painting site is located on the footslope of the Itramuka rift escarpment overlooking Mugori valley [7]. The site occurs on the escarpment's slope in woodland vegetation and has an approximate elevation of $1400 \mathrm{~m}$ a.s.l. This is a combination of a rock shelter and three overhangs, two exterior overhangs and one posterior overhang.

The shelters face south east and east, and it is at least $5.5 \mathrm{~m}$ long and $7.5 \mathrm{~m}$ wide from the modern drip-line to the back wall [7]. There is a large rock (slab) underneath the shelter, which is climbable and may have been used by the painters as a scaffolding to paint the images high up on the shelter. The height of the rock shelter is about $7.5 \mathrm{~m}$ high. About six stone artifacts were spotted on the surface of the shelter's floor. The overhang faces east and is about $5.8 \mathrm{~m}$ long, $2.5 \mathrm{~m}$ wide and $7.4 \mathrm{~m}$ high. The painting subject matter includes naturalistic animals, humans, geometric, and amorphous or abstract figures (Plate 4). This is the most suitable site for public displays, and for tourist treks because the paintings are in a fair to very good state of preservation.

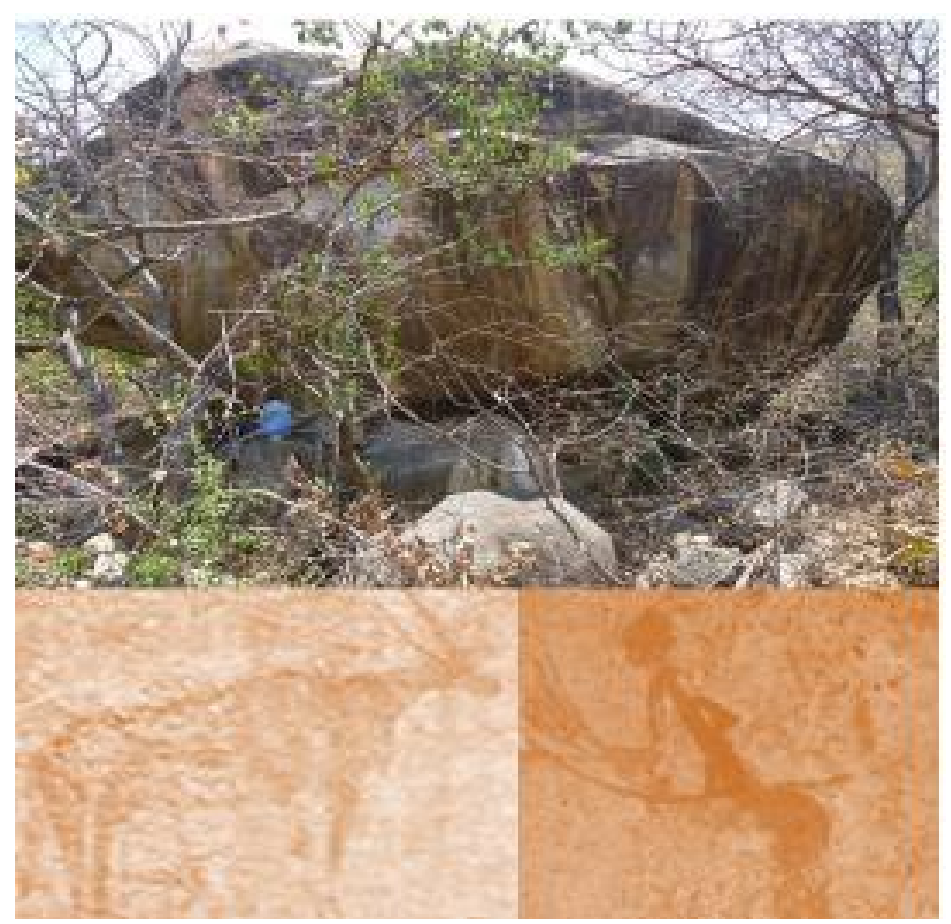

Plate 4. An execution of a hunting scene: naturalistic eland and a human figure at Itramuka rock Shelter (Photo: Courtesy of AZP Mabulla 2014). 


\subsubsection{Misimbwa Rock Shelter (Overhang)}

The shelter has lots of archaeological materials scattered on the floor such as potsherds, slag, bones and lithic artifacts. Surface area of the shelter measures about $115 \mathrm{~m}^{2}$. The site is highly vandalized by iron-smelters and treasure hunters [7]. There is a big hole in shelter probably dug by treasure hunters. The Rock-shelter contains few dusky red geometric paintings. At least 5 figures executed on overhangs' panel. The majority of the paintings are faded due to the anthropogenic, and other chemical actions (Plate 5). The site is not attractive for cultural tourism and public display because of vandalism. The overhang is exposed to wind, rain, temperature, water seepage, biological encrustation, and all of these contribute to the deterioration of the site by the process known as weathering [14]. Water and the organic acids secreted by lichen and other growths can slowly alter a sound and hard rock until it becomes chemically weathered.

The documentation and recording of the Misimbwa rock art were a part of our heritage salvaging mission before the art totally disappeared. This research was facilitated by one of our local informants; Mr Mukhotya Mourice, who informed us about the existence of the paintings in Misimbwa area, and how the site was vandalized by the treasure hunters.

\subsubsection{Siuyu Is an Ideal Place for Tourism Activities in Singida Region}

The archaeology of Siuyu presently can be compared, likened, and be ascertained as similar to Kondoa Irangi, Lake Eyasi basin, Singida north, and Iringa in terms of Later Stone Age (LSA) cultures as depicted by stone tools occurrences, rock art repertoires, and the painting's stylistic affinities. This study refuted the long-time belief and an inherent bias that LSA sites, and rock art sites are only found in Kondoa Irangi in central Tanzania. This fallacy should be completely wiped out; especially in Tanzanian primary schools, and secondary schools' history syllabi whereby for many decades they have been teaching that there are no archaeological or historical sites in Singida region.

Interestingly, this study has revealed the presence of these sites to our villages. For instance, Tanzanian secondary and high school history subject syllabi doesn't mention Singida as a region of uncontested, irrefutable, and incontrovertible archaeological or historical sites in the country. Archaeologically, Singida yields evidence of early human cultural evolution during the Pleistocene period that are contemporaneous to Kondoa, Babati, Lake Manyara basin, and the northern Tanzania highlands of the Iringa region (also see [5] [7] [11]-[15]). More studies should be directed to these areas in order to link the central Tanzanian circuit with northern Tanzania corridor, and the southern highlands of Iringa on research related to the early human biocultural evolution, the emergence of modern human behaviours, and the evolution of cognitive thoughts among prehistoric peoples. These will shed more light on the stone tool use by our ancestors, technological transitions, and early humans' adaptation to semi-arid environments.

Granite outcrop exposures such as Ghodou, Ginyikuuju, Issanga, Itraghattra, Itranghwe, Itranguja, Munini, and the Urimi rock shelters could be optimal avenues for Later Stone Age research (see Plate 6, Figure 3 \& Figure 4). We also have a future plan to undertake multidisciplinary research in a more collaborative manner. This is an appropriate time to address the need for further surveys in the region. In the present instance, it was only possible to conduct an exploratory type survey. In future years, the region should be kept under surveillance in order to take advantage of any newly exposed surfaces which could reveal the existence of further sites within the region.

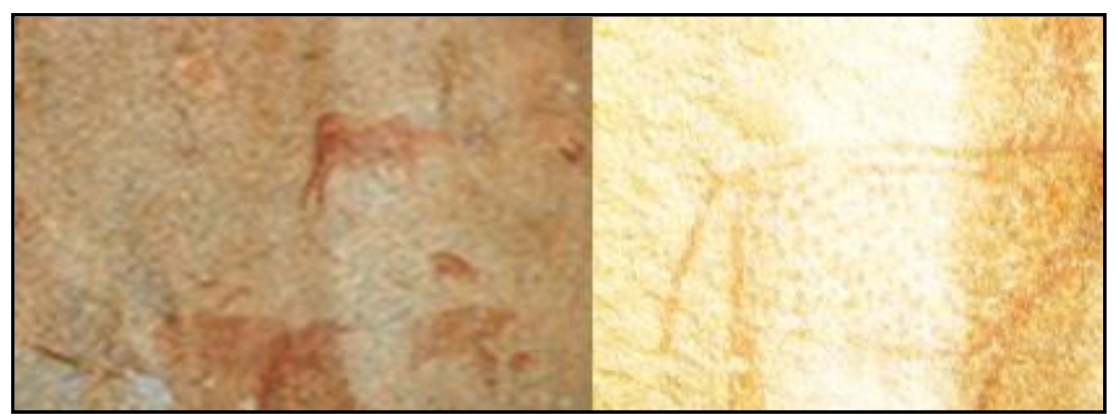

Plate 5. The faded red friezes depicting naturalistic animals, possibly an eland? and a hyena at Misimbwa overhang rock shelter. 


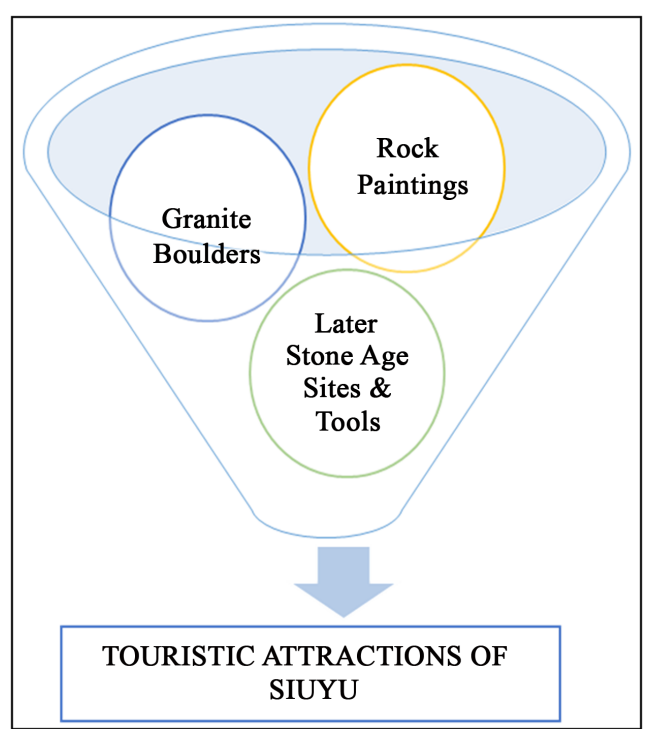

Figure 3. The synergy between natural and cultural touristic attractions of the Siuyu Ward.

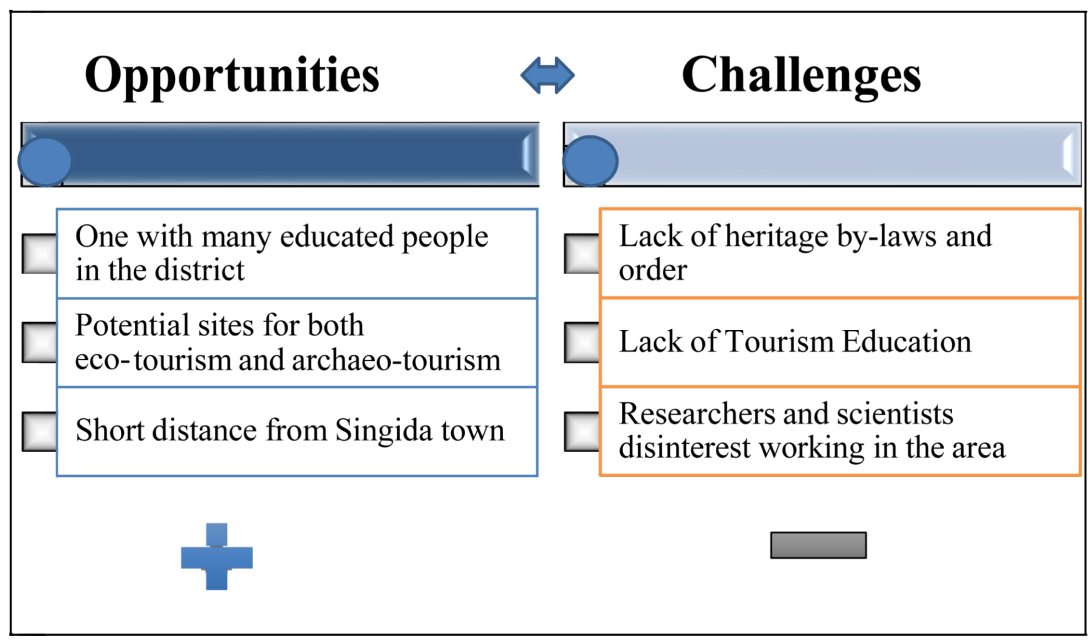

Figure 4. The opportunities for archaeo-tourism \& the threats facing heritage resource conservation and management in Siuyu ward.

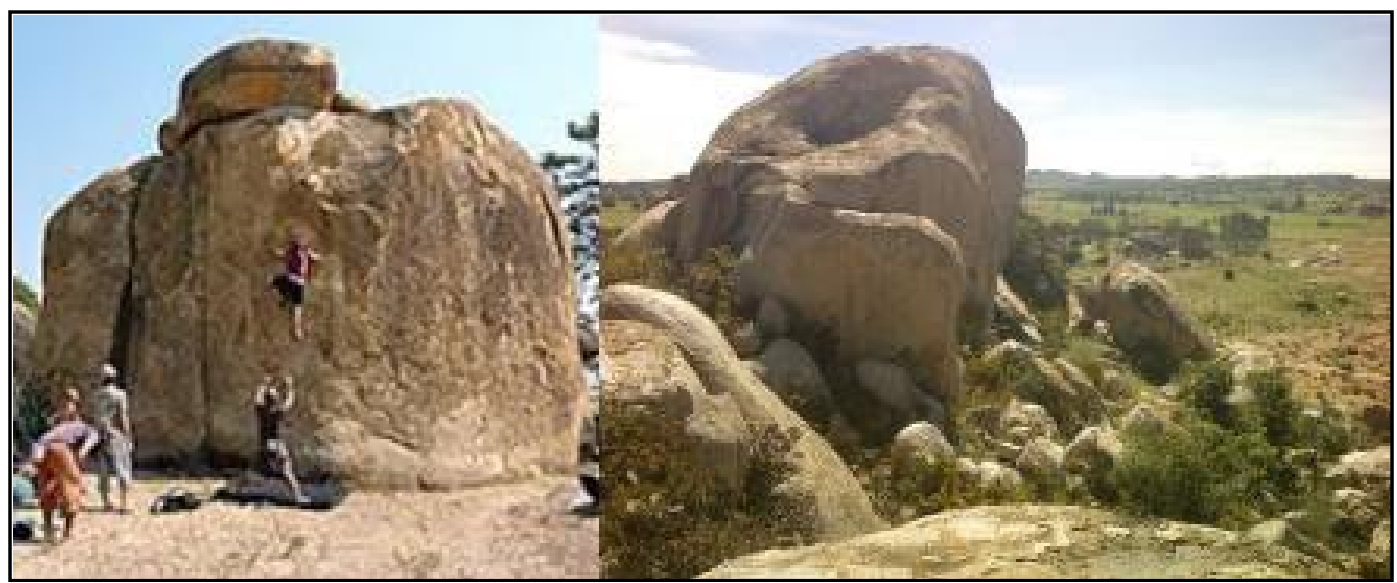

Plate 6. Singida granite rocks have suitable credentials for "rock climbing sports-tourism”. 
It is advised that surveillance be conducted in conjunction with the above recommendations. This would constitute the initial phase in the proper management of the archaeological resources in Siuyu ward and its adjoining localities. Impacts on archaeological resources can vary considerably from partial disturbance to total destruction of archaeological sites. All projects or activities will require an archaeological review to assess the level of threat to an archaeological resource and to determine the degree of mitigation, if any, required to remove or limit the effects of the threat. All the archaeological sites in the Siuyu ward settings are presently in grazing fields used by cattle, goats, donkeys and sheep. This is something that offers the best management option. The regular trampling by larger animals such as donkeys and cattle have caused frequent soil erosion on the wards' landscape.

\section{Discussion}

Despite the fact that the archaeological sites in this locality are highly vandalized by treasure hunters, some of the sites are suitable for archaeo-tourism and public displays. Essentially, the Itramuka rock shelter in Misimbwa has some well-preserved rock paintings that are invaluable assets to the country. These heritage patrimonies need to be publicized, promoted, and protected for sustainable utilization. By doing so, we shall literally make them the tourism attractions of Siuyu ward. If these heritage assets are properly managed, they definitely have the potential to enhance and influence tourist activities in the Siuyu Ward for many decades to come [7]. Some of the rock art sites are in excellent preservation conditions despite the numerous natural elements of deterioration. Vandalism is by far the most deleterious threat as evidenced by the big ditches that were dug under the rock shelters by the treasure hunters.

This is a national problem. Government authorities have done nothing to combat vandalism on heritage sites in Tanzania, and it has been a critical phenomenon which is completely out of control as sites' preservation conditions are worsening continuously. The vandalism occurs, in part, because of a local mythology in Tanzania that the colonialists had buried some treasure, supposedly including German coins and gold. The myth had spread extensively in Tanzania so that almost every painted rock shelter now has its floor excavated, negatively affecting archaeological deposits [13] [14]. With the greed and cupidity for immediate wealth, the treasure hunters set big fires on the base of the shelters or use dynamite to crack or exfoliate the bedrock and more easily excavate the shelters. The majority of the paintings are fainted because of the soot from those fires.

The myth that Germans hidden their rupees (coins) and other precious gems at those sites spread the belief that the paintings were markings executed by the Germans during and after the First World War as identification symbols, landmarks, and/or as the guide beacons to be used by them relocate for shelters under which they buried their treasures [13] [14]. Unfortunately, there is still much evidence that the practice of treasure-hunting continues to this day. The need to educate the local community about the scientific aesthetic and economic values of heritage resources has been forgotten. There is an urgent need for the joint efforts between the local government, the public and the Christian religious institutions in Siuyu to work collaboratively to protect these resources and to promote tourism in this area.

The local community should be sensitized about the significance of these paintings in order to boost and raise community awareness of the value and importance of heritage conservation. In Tanzania, most of the government institutions responsible for cultural heritage management believe that local people, religious institutions, and their respective leaders have no role to play in sustainable heritage management. Lack of heritage conservation education in most parts of Tanzania including Siuyu ward made the local people maintain their belief that rock paintings are signs left by German colonialists to relocate places they buried treasures. With an ever increasingly educated elite in Siuyu as well as the modernization of socio-economic subsistence and other occupational livelihoods, we need to manage the balance: "Modernization pressures of the globalized community vs heritage resources conservation" [4]. This is particularly evident in SiuyuWard whereby at least 95\% of the population practices Catholicism. As a result, the art lost its life, depth and complexity of meaning in the minds of the contemporary generation.

These reasons make it imperative that we should wage deliberate efforts to salvage the rock art of Siuyu in particular, and Singida in general, from total disappearance as a result of development projects, encroachment of civilization, and new religious faiths, and to a lesser extent due to the impacts of climate change in the region [14]. These social-religious factors have to be managed and balanced, specifically by cultural and tourism managers in the region, to offer rights and participation of descendant communities who maintain traditions that in- 
spired art and nature conservation. Such threats need serious mitigation measures; otherwise most of the paintings will disappear. This could be the result of vandalism by treasure hunters and other activities of present day modernization such as an emphasis on the value of digitization and technological advancement, in contrast to valuing traditional practices and technologies.

\section{Conclusions}

The general public, conservators, and managers who deal with cultural-environmental and social factors in tourism should jointly establish a "Heritage Management Plan" for sustainable conservation, management and environmental protection. The proposed Siuyu Heritage Management Plan will benefit the Singida region holistically and provide an integrated approach to archaeological resource identification and protection. The integrated conservation strategies will advocate a clear direction to development proponents, eliminating uncertainty or speculation about the regional archaeological partiality for both eco- and cultural tourism.

The proposed management plan will provide an effective tool for heritage site survey, identification, and conservation for the cultural, tourist guides, stakeholders, and tourism officers in Ikungi district. This can eventually be used by Ikungi municipal cultural officers for the purpose of screening sustainable conservation approaches and ensure archaeological resources are assessed, identified and protected by village authorities, as they are every day custodians and stewards of the archaeological sites [7]. Tourism promotion and outreach campaigns should be launched in Singida eastern axis in order to offer protection that will enhance natural and cultural heritage preservation.

Furthermore, heritage and tourism promotion campaigns [13] [14] will be educating the local people in the development of a procedural framework for efficient land-use decision making that will ensure proper environmental management and protection. These endeavours will require frequent heritage management; promotion campaigns in Ikungi district, and in Singida at large. Linking the villages, wards, districts, and their municipal in strategic initiatives, such as cultural assets survey and mapping, heritage management, documentation, and conservation plans will raise awareness in heritage management and sustainability. Once more, this will help the responsible authorities to develop local policies, procedures and protocols for development and identify appropriate conservation strategies early in the planning process.

\section{Recommendations and the Way Forward}

This paper serves as a wake-up call for the Ikungi district officials that would encourage them to form heritage committees that will preside over the conservation and protection of archaeological resources, natural landscapes, and their environments in general. Tourism and conservation activities will benefit the host community and the nation as well. One can argue that Singida region is "unsung hero" in regards to tourism activities in Tanzania. Despite her beautiful hilly natural landscapes, that are composed of large granite rocks, and many Later Stone Age sites, and rock paintings; the region hasn't been recognised for its tourism potentiality until now.

Many conservation efforts in Tanzania have been directed to the national parks, game reserves, built monuments, ruins, and other areas with wild games. Unfortunately, the ecologically and geologically spectacular areas like Singida has been completely deserted and neglected by the responsible authorities i.e. the Ministry of Natural Resources and Tourism of Tanzania. If they are properly advertised, the huge granite rock boulders of Singida can furnish an outstanding contribution to the tourism industry. Similarly, in most parts of America, Australia, and Europe, there are popular hiking sports i.e. “Rock Climbing Sports' that annually gathers people to compete in climbing the huge boulders with higher peaks, rough surface, and the most difficult to climb rocks. This is a game in which participants climb up, down or across natural rock formations for fun or for professional competitions. The goal is to reach the summit of a rock or the endpoint of a usual pre-defined route without falling. Professional rock climbing competitions have the objectives of either completing the route in the quickest possible time or attaining the farthest point on an increasingly difficult route. The Siuyu locals should regularly partake in this sport, and the rocks can be marketed as a location for rock climbing sports. This sport is a healthy game, physically, and mentally refreshing sport that tests a climber's strength, endurance, agility and balance along with mental control.

Therefore, it is crucial to advocate on the synergistic potentialities of integrating archaeological sites e.g. rock painting sites and natural granite rock boulders for tourism endeavours in Siuyu ward, and in Singida regionally (Figure 3 and Figure 4). No any single area has many rock painting sites in Tanzania than the Singida region 
does; even the so famous, glorified, and well celebrated Kondoa Irangi (World Heritage Site), has fewer sites than Singida. The mistakes made by ignoring the Singida sites are largely because they are isolated and scattered, not clustered like the Kondoa Irangi sites. The fame of Kondoa paintings emanates from the fact that they are located on a series of closely spaced shelters, an alignment of many rock shelters along the granitoid slopes of the Maasai escarpment. Because of their east-west axis alignment, a visitor can have a tour of all the sites just for a day only while in Singida several days are needed to visit a majority of the painting sites. Accordingly, we are calling for the joint conservation efforts that would give hope for future sustainable use of Singida's patrimonies.

\section{Acknowledgements}

Many thanks to the local informants of the Siuyu ward who provided us with the warm reception, invaluable support, and by showing to us the location of the rock shelters. These informants are: Silvery Labia Mujju, Mourice Moukhotrya, Joseph Trathri, Ambrose Leo Deede, Qiimu Senani, and Thomas Telesphory Mungwabi (Mwajîfya inno ahumba va ukhaya, njarîyi káangî nnēnathrîe ü ng’ongo ă ikhăkha!!). Any new ideas, new aspects or arguments in this paper are the opinions of the authors. Lastly, we would like to extend our heartfelt thanks to Linda Sunderland for the edits of the manuscript, Linda we owe you an unbearable debt that we can't afford to pay back!

\section{Disclosure}

No potential conflict of interest is reported by either author.

\section{References}

[1] Masao, F.T. (1976) Some Common Aspects of the Rock Paintings of Kondoa and Singida Central, Tanzania. Tanzania Notes and Records, 77-78, 51-64.

[2] Mahudi, H. (2008) The Use of Rock Art in Understanding of Socio-Economic Activities and Cultural Values: The Case of Matongo-Isanzu in Iramba District, Tanzania. Unpublished MA Dissertation.

[3] Itambu, M.P. (2013) The Rock Art of Iringa Region, Southern Tanzania. A Descriptive and Comparative Study. MA Dissertation, University of Dar Es Salaam.

[4] Itambu, M.P. (2016) Managing the Balance: Ecological Pressures and Heritage Resources in Rungwe District, Southern Highlands of Tanzania. Journal of Geoscience and Environment Protection, 4, 79-90. http://dx.doi.org/10.4236/gep.2016.43007

[5] Leakey, M. (1983) Africa’s Vanishing Art: The Rock Art of Tanzania. Doubleday and Company, New York.

[6] Masao, F.T. (2007) The Rock Art of Singida and Lake Eyasi in Tanzania. Unpublished MA Dissertation.

[7] Mabulla, A.Z.P., Itambu, M.P. and Mabulla, I.M. (2016) The Cultural Treasures of Central and Eastern Singida Region, Tanzania.

[8] Schaniel, W.C. (1982) The Wahi Wanyaturu and the Market. Journal of Economic Issues, 16, 445-452. http://dx.doi.org/10.1080/00213624.1982.11504002

[9] Mannard, G.W. (1962) The Geology of the Singida Kimberlite Pipes, Tanganyika. Ph.D. Thesis, McGill University, Montreal.

[10] (2000) Government of Tanzania Population and Housing Census General Report.

[11] Schneider, H.K. (1970) The Wahi Wanyaturu: Economics; in an African Society, Viking Fund Publications in Anthropology, No. 48.

[12] Kohl-Larsen, L. and Kohl-Larsen, M. (1958) Die Bilderstress Ostafrikas. Erich Roth, Kassel.

[13] Itambu, M.P. (2015) Rediscovering the Intriguing Patrimonies Depicted in Rock Shelters of Iringa, Tanzania. In: Runge, J., Ed., Changing Climates, Ecosystems and Environments within Arid Southern Africa and Adjoining Regions: Palaeoecology of Africa, 33, 175-190. http://dx.doi.org/10.1201/b19410-11

[14] Itambu, M.P. and Bushozi, P.G.M. (2015) The Rock Art of Iringa Region: Studies in the African Past. The Journal of African Archaeology Network Vol. 11 E and D Vision Publishing Limited, Dar Es Salaam.

[15] Mabulla, I.A.M. (2014) Making Sense of a Fragmentary Past: The Rock Art of Simiyu Region, Lake Victoria Basin, Tanzania: Instituto Politécnico de Tomar, Universidade de Trás-os-Montes e Alto Douro (Departamento de Geologia da UTAD, Departamento de Território, Arqueologia e Património do IPT): Unpublished Masters Dissertation. 